\title{
Orthodontic cements: Immediate protection and fluoride release
}

Rogério Lacerda dos Santos', Matheus Melo Pithon², Júlia Barbosa Pereira Leonardo³, Edna Lúcia Couto Oberosler, Delmo Santiago Vaitsman ${ }^{5}$, Antônio Carlos de Oliveira Ruellas ${ }^{6}$

Objectives: The objective of the authors was to evaluate fluoride release of 3 glass ionomer cements with immediate protection of fluoride varnish (Cavitine, SS White), divided into 3 groups: Group M (Meron, VOCO), Group V (Vidrion C, SS White) and Group KC (Ketac-Cem, 3M ESPE).

Methods: Fluoride release was measured during 60 days by means of an ion-selective electrode connected to an ion analyzer. After 4 weeks, the test specimens were exposed to a solution of $0.221 \%$ sodium fluoride (1000 ppm of fluoride).

Results: Results showed that the cements reached a maximum peak of fluoride release in a period of $24 \mathrm{~h}$. There was a statistically significant difference between the amount of fluoride released after the applications of fluoride among the groups from the 31st to 60th day ( $\mathrm{p}>0.05)$.

Conclusion: The Vidrion C and Meron cements showed better performance to uptake and release fluoride when compared with Ketac-Cem cement.

Keywords: Glass ionomer cement. Fluoride release. Varnish.

${ }^{1}$ Specialist in Orthodontics, Alfenas Federal University. MSc and PhD in Orthodontics, Rio de Janeiro Federal University. Adjunct Professor of Orthodontics, Federal University of Campina Grande.

${ }^{2}$ Specialist in Orthodontics, Alfenas Federal University. MSc and $\mathrm{PhD}$ in Orthodontics, Rio de Janeiro Federal University. Assistant Professor of Orthodontics, Sudoeste da Bahia State University.

${ }^{3}$ Graduation in Dentistry, Rio de Janeiro Federal University.

${ }^{4}$ Professor of Analytical Chemistry Department, LaDA - IQ/UFRJ.

${ }^{5} \mathrm{PhD}$ in Chemistry, Pontifical Catholic University of Rio de Janeiro. Adjunct Professor of the Analytical Chemistry Department, LaDA - IQ/UFRJ.

${ }^{6} \mathrm{MSc}$ and $\mathrm{PhD}$ in Orthodontics, Rio de Janeiro Federal University. Associated Professor of the Pediatric Dentistry and Orthodontics Department of Rio de Janeiro Federal University.

\author{
How to cite this article: Santos RL, Pithon MM, Leonardo JBP, Oberosler ELC, \\ Vaitsman DS, Ruellas ACO. Orthodontic cements: Immediate protection and fluoride \\ release. Dental Press J Orthod. 2012 July-Aug;17(4)::27.el-5. \\ Submitted: August 21, 2008 - Revised and accepted: November 24, 2008 \\ » The authors report no commercial, proprietary or financial interest in the products \\ or companies described in this article. \\ Contact address: Rogério Lacerda dos Santos \\ Universidade Federal de Campina Grande - UFCG \\ Centro de Saúde e Tecnologia Rural (CSTR) - Av. dos Universitários, s/n, \\ Rodovia Patos-Teixeira, Km 1, Santa Cecília - Patos/PB, Brazil \\ Zip code: 58.700-970 - E-mail: lacerdaorto@hotmail.com
}




\section{Cimentos ortodônticos: proteção imediata e liberação de flúor}

Rogério Lacerda dos Santos', Matheus Melo Pithon², Júlia Barbosa Pereira Leonardo ${ }^{3}$ Edna Lúcia Couto Oberosler, Delmo Santiago Vaitsman ${ }^{5}$, Antônio Carlos de Oliveira Ruellas ${ }^{6}$

Objetivo: o objetivo desse estudo foi avaliar a liberação de flúor dos seguintes três cimentos de ionômero de vidro, com proteção imediata de verniz fluoretado (Cavitine, S. S. White): Meron / VOCO (Grupo M); Vidrion C / S. S. White (Grupo V); e Ketac Cem / 3M ESPE (Grupo KC).

Métodos: a liberação de flúor foi medida durante 60 dias, através de eletrodo íon seletivo conectado a um analisador de íons. Após quatro semanas, os corpos de prova foram expostos a uma solução de fluoreto de sódio a $0,221 \%$ (1.000ppm de flúor).

Resultados: os resultados evidenciaram que os cimentos atingiram o pico máximo de liberação de flúor com 24h após a presa inicial. Houve diferença estatisticamente significativa entre os grupos, quanto à quantidade de flúor liberado após as aplicações de flúor, do $31^{\circ}$ ao $60^{\circ}$ dia $(\mathrm{p}>0,05)$.

Conclusão: os cimentos Meron e Vidrion apresentaram maior capacidade de captação e liberação de flúor, em comparação ao cimento Ketac Cem.

Palavras-chave: Cimento de ionômero de vidro. Liberação de flúor. Verniz.

${ }^{1}$ Especialista em Ortodontia pela Universidade Federal de Alfenas. Mestre e Doutor em Ortodontia pela Universidade Federal do Rio de Janeiro. Professor Adjunto de Ortodontia da Universidade Federal de Campina Grande.

${ }^{2}$ Especialista em Ortodontia pela Universidade Federal de Alfenas. Mestre e Doutor em Ortodontia pela Universidade Federal do Rio de Janeiro. Professor Assistente de Ortodontia da Universidade Estadual do Sudoeste da Bahia.

${ }^{3}$ Graduada em Odontologia pela Universidade Federal do Rio de Janeiro.

${ }^{4}$ Professor do Departamento de Química Analítica - LaDA - IQ/UFRJ.

${ }^{5}$ Doutor em Química pela Pontifícia Universidade Católica do Rio de Janeiro. Professor Adjunto do Laboratório de Química Analítica da Universidade Federal do Rio de Janeiro.

${ }^{6}$ Mestre e Doutor em Ortodontia pela Universidade Federal do Rio de Janeiro. Professor Associado do Departamento de Odontopediatria e Ortodontia da Universidade Federal do Rio de Janeiro.
Como citar este artigo: Santos RL, Pithon MM, Leonardo JBP, Oberosler ELC, Vaitsman DS, Ruellas ACO. Orthodontic cements: Immediate protection and fluoride release. Dental Press J Orthod. 2012 July-Aug;17(4):27.el-5.

Enviado em: 21 de agosto de 2008 - Revisado e aceito: 24 de novembro de 2008

» Os autores declaram não ter interesses associativos, comerciais, de propriedade ou financeiros que representem conflito de interesse nos produtos e companhias descritos nesse artigo.

Endereço para correspondência: Rogério Lacerda dos Santos Universidade Federal de Campina Grande - UFCG Centro de Saúde e Tecnologia Rural (CSTR) - Av. dos Universitários, s/n, Rodovia Patos-Teixeira, Km 1, Santa Cecília - Patos/PB - CEP: 58.700-970 E-mail: lacerdaorto@hotmail.com 


\section{INTRODUCTION}

Decalcifications on the dental surfaces adjacent to brackets occur frequently in orthodontic treatments. ${ }^{18}$ In order to reduce the occurrence of demineralization, fixation of devices must be made using a material that is capable of releasing fluoride, providing adequate bonding to enamel and to the brackets ${ }^{5}$.

Although glass ionomer cement (GIC) is a widely used material in orthodontics, some of its properties are not yet completely satisfactory..$^{15}$ Therefore, it is extremely important for orthodontists to know the properties of the material that they use in office, being aware both of their advantages as well as their limitations. ${ }^{1}$ During the initial setting stage, glass ionomer cements are more susceptible to hygroscopic alteration of the environment. It may suffer syneresis and imbibition processes, which are the loss or gain of water from the external environment, respectively. This contamination affects the physical properties of bonding and increases the chances of the material disintegrating. To prevent this from occurring, immediate protection of the surfaces of GIC with sealing materials such as varnishes is recommended. ${ }^{4,10}$ It takes $24 \mathrm{~h}$ for GIC to set completely and reach maximum strength force ${ }^{21}$. This occurs due to the extremely slow release of aluminum ions from the glass powder. Since the material is not completely hardened, the first 24 hours after application of this material are critical. ${ }^{19}$

Recent studies have shown fluoride release from ionomer materials which were exposed to a fluoride recharge, for a short period of time and at intervals of days, ${ }^{17}$ or for only one day of exposure. ${ }^{8}$ The aim of this study was to test fluoride release before and after recharge of conventional glass ionomer cements.

\section{MATERIAL AND METHODS}

To evaluate fluoride release, the materials were divided into 3 groups: Group M (Meron, VOCO, Cuxhaven, Germany), Group V (Vidrion C, SS White, Rio de Janeiro, Brazil) and Group KC (Ketac-Cem, 3M ESPE, Seefeld, Germany).

The test specimens were fabricated using silicone molds measuring $4 \mathrm{~mm}$ in diameter and $4 \mathrm{~mm}$ high (Fig 1). The material was inserted into the molds with the aid of a syringe (Centrix, DFL, Rio de Janeiro, Brazil), preventing the formation of bubbles.
The surface of the test specimens was covered with glass slides under digital pressure, planarizing the surface of the material. The cements were kept under pressure for 10 minutes. The application of fluoride varnish (Cavitine, SSWhite, Rio de Janeiro, Brazil) on the surface of the GIC cylinders was performed immediately after removing the excess of cement and they were lightly dried with jets of air using a triple syringe. All the materials were manipulated by a single operator in accordance with the manufacturer's instructions.

Thirty test specimens were made, ten specimens for each one of the cements, which were protected with varnish and kept in a humidifier at $37^{\circ} \mathrm{C}$ and $100 \%$ of humidity for 30 minutes. After this period, 2 test specimens were placed in $8 \mathrm{~mL}$ of deionized water through the Milli- $Q$ purification system (Millipore, Bedford, MA, USA) and placed in a glass receptacle. The glass receptacles were kept in an oven at $37^{\circ} \mathrm{C}$ (bacteriological oven, type $\mathrm{B} 2 \mathrm{C}$, number 105) during the study. The test specimens were lightly dried with absorbent sheets of paper every $24 \mathrm{~h}$ and the water of each receptacle was changed. This procedure was carried out to prevent the accumulation of fluoride and to evaluate daily fluoride release. ${ }^{14}$

To wash the test specimens $8 \mathrm{~mL}$ of solution and $2 \mathrm{~mL}$ of deionized water were mixed and diluted 5 times and adjusted with $50 \mathrm{~mL}$ of total ionic strength adjustment buffer (TISAB). The concentrations of fluoride were analyzed through an ion-selective electrode (Thermo Orion Model 9609, Orion Research Inc., Boston, MA) connected to an ion analyzer ( $\mathrm{Ph} /$ ion, 450 M, Analyzer, São Paulo, Brazil). The electrode was daily calibrated with standard fluoride solutions of $0.05,0.10,0.19 \mathrm{ppm}$. Readings were made to assess the concentrations of fluoride release from each material and the data transformed into $\mu \mathrm{g} / \mathrm{cm}^{2}$ in order to show the amount of fluoride released per area of the test specimen. Fluoride release was measured after $1 \mathrm{~h}$ and 2, 3, 7, 14, 21 and 28 days.

After 4 weeks, the test specimens were rinsed with deionized water for 20 seconds and the surface was lightly dried with disposable absorbent paper and exposed to a solution of $0.221 \%$ sodium fluoride (1000 ppm of fluoride) (School Pharmacy, Federal University of Rio de Janeiro, UFRJ) on day 28 for 5 minutes and then rinsed with deionized water for 20 seconds. 
Two test specimens were placed in $8 \mathrm{~mL}$ of deionized water in a glass receptacle and fluoride release was measured after $24 \mathrm{~h}$ and $48 \mathrm{~h}$ (on days 29 and 30) to observe the release time of absorbed fluoride. On days 30,31 and 32 , new fluoride recharge was made, as previously described, and evaluated $24 \mathrm{~h}$ after the procedure (days 31, 32 and 33) to observe capacity of maintenance of recharge. New evaluations were

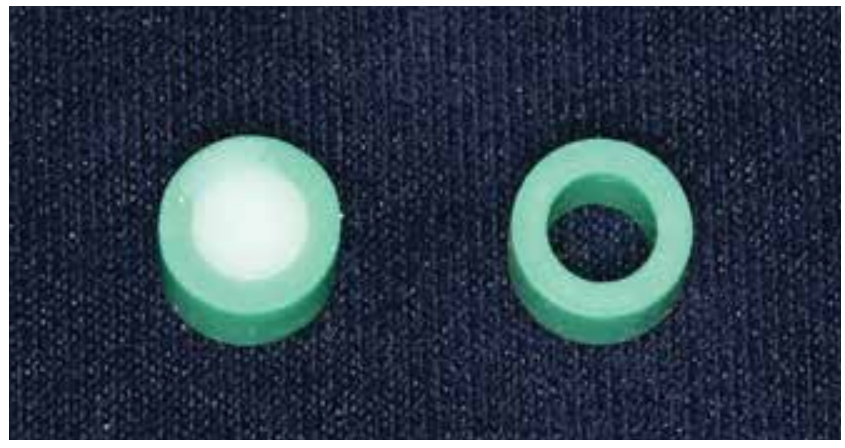

Figure 1 - Silicone molds used to fabricate the test specimens.

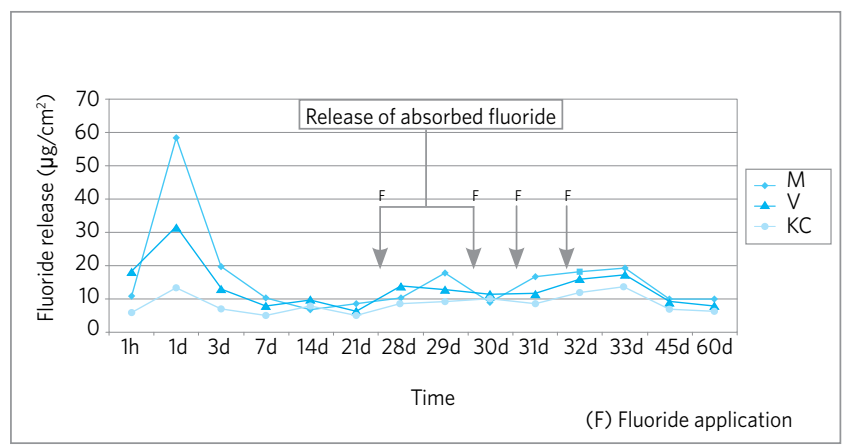

Figure 2 - Amount of fluoride released for each one of the cements during the period assessed. made after 45 and 60 days with the purpose of verifying the behavior of the cements after 15 and 30 days of recharge. Deionized water was used instead of distilled water, since deionized water does not have ions and the presence of ions might have interfered in the results.

Analysis of variance, multiple comparison (ANOVA) and Kruskal-Wallis tests were used for the evaluation between the groups with reliability at a level of significance of 0.05 to identify the statistical difference in fluoride release.

\section{RESULTS}

The amount of fluoride released by each cement during the period assessed is shown in Figure 2. The standard fluoride release was similar for the different cements assessed. All the materials showed greater fluoride release on the first day and a rapid decrease up to the seventh day, but there was a difference in the amount of fluoride released. Table 1 shows fluoride release of materials after daily changes of Milli-q water.

Table 2 shows fluoride release of materials after immersion in the sodium fluoride solution. On day 28 , before application of fluoride, the amount of fluoride released from Vidrion was higher than for the other materials, but there was a statistically significant difference among the groups $(\mathrm{p}<0.05)$.

On day 29, the first day after application of fluoride, there was a statistically significant difference

Table 1 - Fluoride release of ionomer cements during 28 days.

\begin{tabular}{cccccccc}
\hline GIC & $\mathbf{1}$ hour & $\mathbf{1}$ day & $\mathbf{3}$ days & $\mathbf{7}$ days & $\mathbf{1 4}$ days & $\mathbf{2 1}$ days & $\mathbf{2 8}$ days \\
\hline $\mathrm{M}$ & $10.58(1.20)$ & $58.43(2.89)$ & $19.50(2.17)$ & $10.03(0.41)$ & $6.60(0.56)$ & $8.28(0.41)$ & $10.03(0.41)$ \\
$\mathrm{V}$ & $17.91(2.81)^{\mathrm{a}}$ & $31.68(2.84)^{\mathrm{a}}$ & $12.73(1.76)^{\mathrm{a}}$ & $7.80(2.26)^{\mathrm{a}}$ & $9.39(0.56)^{\mathrm{a}}$ & $6.21(0.68)^{\mathrm{a}}$ & $13.77(0.50)^{\mathrm{a}}$ \\
$\mathrm{KC}$ & $5.65(1.07)^{\mathrm{b}}$ & $12.97(2.80)^{\mathrm{ab}}$ & $6.84(0.48)^{\mathrm{ab}}$ & $4.69(0.16)^{\mathrm{ab}}$ & $7.80(0.33)^{\mathrm{ab}}$ & $4.69(0.16)^{\mathrm{ab}}$ & $8.28(0.16)^{\mathrm{ab}}$ \\
\hline
\end{tabular}

$\mathrm{N}=10$, Mean (standard deviation), ${ }^{a}(p<0.05)$ compared to group $M .{ }^{b}(p<0.05)$ compared to group V. Significant statistical difference observed between groups for the same analyzed time.

Table 2 - Fluoride release of ionomer cements after application of fluoride.

\begin{tabular}{ccccccccc}
\hline GIC & $\mathbf{2 8}$ days & $\mathbf{2 9}$ days & $\mathbf{3 0}$ days & $\mathbf{3 1}$ days & $\mathbf{3 2}$ days & $\mathbf{3 3}$ days & $\mathbf{4 5}$ days & $\mathbf{6 0}$ days \\
\hline $\mathrm{M}$ & $10.03(0.41)$ & $17.51(1.59)$ & $8.75(0.53)$ & $16.79(0.61)$ & $18.07(0.82)$ & $19.02(1.00)$ & $9.55(1.23)$ & $9.75(0.81)$ \\
$\mathrm{V}$ & $13.77(0.50)^{\mathrm{a}}$ & $12.74(0.75)^{\mathrm{a}}$ & $11.06(1.51)^{\mathrm{a}}$ & $11.30(0.82)^{\mathrm{a}}$ & $15.76(0.82)^{\mathrm{a}}$ & $17.19(0.93)^{\mathrm{a}}$ & $8.75(0.91)^{\mathrm{a}}$ & $7.99(0.93)^{\mathrm{a}}$ \\
$\mathrm{KC}$ & $8.28(0.16)^{\mathrm{ab}}$ & $8.99(0.50)^{\mathrm{ab}}$ & $9.55(0)^{\mathrm{b}}$ & $8.12(0.33)^{\mathrm{ab}}$ & $11.38(0.62)^{\mathrm{ab}}$ & $13.45(0.61)^{\mathrm{ab}}$ & $6.76(0.66)^{\mathrm{ab}}$ & $6.13(0.71)^{\mathrm{ab}}$ \\
\hline
\end{tabular}

$\mathrm{N}=10$, Mean (standard deviation), ${ }^{a}(p<0.05)$ compared to group $M .{ }^{b}(p<0.05)$ compared to group $V$. Significant statistical difference observed between groups for the same analyzed time. 
among the groups $(\mathrm{p}<0.05)$. On day 30 , which corresponds to $48 \mathrm{~h}$ after the first recharge of fluoride, there was no statistically significant difference between the groups $\mathrm{M}$ and $\mathrm{KC}(\mathrm{p}>0.05)$.

There was a statistically significant difference between the amount of fluoride released after the applications of fluoride among the groups from the $31^{\text {st }}$ day to the $60^{\text {th }}$ day $(\mathrm{p}<0.05)$. On days 32 and 33 , all the cements showed greater fluoride release, which shows the capacity of uptake and accumulation of fluoride after recharge. On the $45^{\text {th }}$ and $60^{\text {th }}$ day, significant decrease of fluoride release was observed for the three cements with values close to the ones observed on the $7^{\text {th }}$ and $28^{\text {th }}$ day.

\section{DISCUSSION}

It has been widely reported that GIC or other materials that contain fluoride present a cariogenic inhibitory effect when compared with composites without fluoride, as observed by Kielbassa et $\mathrm{al}^{12}$ and this inhibition is fundamental in orthodontic treatment. The fluoride solution used was at a concentration of $1000 \mathrm{ppm} \mathrm{NaF}$, similar to the concentration of dentifrices used for dental toothbrushing, according to Okuyama et al. ${ }^{16}$

Fluoride release was evaluated for 4 weeks with the purpose of observing the performance of the material during this period, since patients with fixed appliances normally visit the orthodontist once a month. In this study, a protocol of daily water change was used to assess fluoride release, for this protocol is better than the accumulation of fluoride in a solution. ${ }^{20}$

Caves et $\mathrm{al}^{3}$ reported that the type of cement, the geometric model and surface area may significantly influence fluoride release, but there is no standardized size for test specimens to assess fluoride release, which are diverse in other studies. ${ }^{6}$ The present study used disks measuring $4 \mathrm{~mm}$ in diameter and $4 \mathrm{~mm}$ high.

Fluoride release found in glass ionomer cements was higher $24 \mathrm{~h}$ after initial setting and decreased after 3 and 7 days. After the $7^{\text {th }}$ day, there was small variation and fluoride release was constant, which is similar to the findings of Komori and Kojima ${ }^{13}$ and Kuvvetli et al ${ }^{14}$ (Fig 1). This characteristic is clinically relevant for cementation materials and the 3 cements maintained a small difference of fluoride release after the $7^{\text {th }}$ day. The cements that showed better performance were
Meron and Vidrion, which may mean a greater clinical effect for preventing enamel demineralization when compared with Ketac-Cem.

Meron cement showed good performance, which corroborates the findings of Akkaya et al, ${ }^{2}$ a performance close to the one found for Vidrion cement and better than Ketac-Cem, which showed a lower value than the one found by Komori and Kojima. ${ }^{13}$ Fluoride release of Ketac-Cem was significantly lower than the one found for the other 2 ionomer cements, but release showed to be detectable during the entire experiment which, according to Dijkman et al, ${ }^{7}$ is fundamental during orthodontic treatment.

After one day of fluoride release, the 3 cements Meron, Ketac-Cem and Vidrion showed greater fluoride release when compared to the time interval of $1 \mathrm{~h}$, which shows that these cements reach a maximum peak of fluoride release after $24 \mathrm{~h}$ of initial setting, with a statistically significant difference $(\mathrm{p}<0.05)$. On the $7^{\text {th }}, 14^{\text {th }}, 21^{\text {st }}$ and $28^{\text {th }}$ day, the cements showed a similar fluoride release pattern, but with lower values than at the time intervals of $1 \mathrm{~h}, 1$ day and 3 days. This shows that despite the three cements presenting lower values of fluoride releases after the $7^{\text {th }}$ day, the values were detectable during the entire experiment.

The amount of fluoride recharge may depend on the capacity of intrinsic fluoride release of each material, since the sites occupied by intrinsic fluoride are fixed and limited inside them. ${ }^{11}$ The cements that showed greater initial fluoride release presented greater fluoride release during the entire experiment, which suggests a greater capacity of fluoride recharge, being in agreement with the findings of $\mathrm{Xu}$ and Burgees. ${ }^{22}$ Fluoride released after the period of exposure of recharge has a tendency to release the same amount as the initial period, ${ }^{16}$ which may be observed during the application period of fluoride from day 29 to day 33. Fluoride release observed after 45 and 60 days showed values close to the ones observed on the $7^{\text {th }}$ and $28^{\text {th }}$ day, which suggests that, after these values, fluoride release tends to slowly diminish, being detectable after longer periods.

Material porosity may influence the amount of fluoride released before and after recharge, in accordance with Xu and Burgess. ${ }^{22}$ Obviously, greater porosity enables greater diffusion of fluoride recharge and results in a larger amount of storage and release. 
Resin-reinforced glass ionomer cements present less porosities than conventional GIC and therefore, lower fluoride release, which corroborates the findings of Komori and Kojima ${ }^{13}$ and Kuvvetli et al. ${ }^{14}$

In an in vivo study, Hallgren et $\mathrm{al}^{9}$ observed that brackets and bands cemented with GIC significantly increased the concentration of fluoride in saliva. However, it is suggested that the orthodontic bands should be regularly checked because fluoride release may not completely inhibit developing caries lesion in the bands, which may be loose or in areas that are without GIC.

\section{CONCLUSION}

It could be concluded that:

1) Immediate protection with fluoride varnish reduces the risk of syneresis and imbibition and do not inhibit fluoride release.

2) Meron and Vidrion cements presented greater capacity of fluoride uptake and release than KetacCem cement.

3) The amount of fluoride release in the three cements increased after recharge. Thus, the use of fluoride mouthrinses is suggested as an alternative to increase the amount of fluoride released by GICs.

\section{REFERENCES}

1. Aguiar DA, Silveira MR, Ritter DE, Locks A, Calvo MCM. Avaliação das propriedades mecânicas de quatro cimentos de ionômero de vidro convencionais utilizados na cimentação de bandas ortodônticas. Rev Dent Press Ortodon Ortop Facial. 2008 Maio-Jun;13(3):104-11.

2. Akkaya $S$, Uner O, Alaçam A, Değim T. Enamel fluoride levels after orthodontic band cementation with glass ionomer cement. Eur J Orthod. 1996 Feb;18(1):81-7.

3. Caves GR, Millett DT, Creanor SL, Foye RH, Gilmour WH. Fluoride release from orthodontic band cements-a comparison of two in vitro models. J Dent. 2003 Jan;31(1):19-24.

4. Chuang SF, Jin YT, Tsai PF, Wong TY. Effect of various surface protections on the margin microleakage of resin-modified glass ionomer cements. J Prosthet Dent. 2001 Sep;86(3):309-14

5. Cohen WJ, Wiltshire WA, Dawes C, Lavelle CL. Long-term in vitro fluoride release and rerelease from orthodontic bonding materials containing fluoride. Am J Orthod Dentofacial Orthop. 2003 Nov;124(5):571-6.

6. Creanor SL, Al-Harthy NS, Gilmour WH, Foye RH, Rogers I, Millett DT. Fluoride release from orthodontic cements-effect of specimen surface area and depth. J Dent. 2003 Jan;31(1):25-32.

7. Dijkman GE, de Vries J, Lodding A, Arends J. Long-term fluoride release of visible light-activated composites in vitro: a correlation with in situ demineralisation data. Caries Res. 1993;27(2):117-23.

8. Donly KJ, Nelson JJ. Fluoride release of restorative materials exposed to a fluoridated dentifrice. ASDC J Dent Child. 1997 Jul-Aug;64(4):249-50.

9. Hallgren A, Oliveby A, Twetman S. Salivary fluoride concentrations in children with glass ionomer cemented orthodontic appliances. Caries Res. 1990;24(4):239-41.

10. Hattab FN, Amin WM. Fluoride release from glass ionomer restorative materials and the effects of surface coating. Biomaterials. 2001 Jun;22(12):1449-58.

11. Itota T, Carrick TE, Yoshiyama M, McCabe JF. Fluoride release and recharge in giomer, compomer and resin composite. Dent Mater. 2004 Nov;20(9):789-95.
12. Kielbassa AM, Schulte-Monting J, Garcia-Godoy F, Meyer-Lueckel H. Initial in situ secondary caries formation: effect of various fluoride-containing restorative materials. Oper Dent. 2003 Nov-Dec;28(6):765-72.

13. Komori A, Kojima I. Evaluation of a new 2-paste glass ionomer cement. Am J Orthod Dentofacial Orthop. 2003 Jun;123(6):649-52.

14. Kuvvetli SS, Tuna EB, Cildir SK, Sandalli N, Gençay K. Evaluation of the fluoride release from orthodontic band cements. Am J Dent. 2006 Oct;19(5):275-8.

15. Mount GJ. Clinical performance of glass-ionomers. Biomaterials. 1998 Mar;19(6):573-9.

16. Okuyama K, Murata Y, Pereira PN, Miguez PA, Komatsu H, Sano H. Fluoride release and uptake by various dental materials after fluoride application. Am J Dent. 2006 Apr;19(2):123-7.

17. Suljak JP, Hatibovic-Kofman S. A fluoride release-adsorption-release system applied to fluoride-releasing restorative materials. Quintessence Int. 1996 Sep;27(9):635-8.

18. Thilander BL. Complications of orthodontic treatment. Curr Opin Dent. 1992 Dec;2:28-37.

19. Ian Matos Vieira IM, Louro RL, Atta MT, Navarro MFL, Francisconi PAS.O cimento de ionômero de vidro na odontologia. Rev Saúde com. 2006;2(1):75-84.

20. Wheeler AW, Foley TF, Mamandras A. Comparison of fluoride release protocols for in-vitro testing of 3 orthodontic adhesives. Am J Orthod Dentofacial Orthop. 2002 Mar;121(3):301-9.

21. Wilson AD, Paddon JM, Crisp S.The hydration of dental cements. J Dent Res. 1979 Mar;58(3):1065-71.

22. $\mathrm{Xu} X$, Burgess JO.Compressive strength, fluoride release and recharge of fluoridereleasing materials. Biomaterials. 2003 Jun;24(14):2451-61. 